\title{
Analysis of Hard Facing Material Designed for Application on the Forestry Tools
}

\author{
Miroslava Ťavodová', Michaela Hnilicová', Izabela Miturska \\ 1 Technical University in Zvole, Faculty of Environmental and Manufacturing Technology, Študentská 26, \\ 96001 Zvolen, Slovakia \\ 2 Lublin University of Technology, Faculty of Mechanical Engineering, Nadbystrzycka 36, 20-618 Lublin, Poland \\ * Corresponing author's e-mail: i.miturska@pollub.pl
}

\begin{abstract}
The article deals with the assessment specific hard facing material with $\mathrm{W}_{2} \mathrm{C}$ high content - filled welding rod for manual flame hard facing RD 571. Is was applied in two layers on the samples (16MnCr5 steel) of the tool for crushing undesirable advance growths, frequently used in forestry technologies. The tools work in a heterogeneous environment. They are loaded by abrasive impression of wood mass, which are characterized by various hardness. The material loss on the functional parts is significant. The wear degradation of the tool and its subsequent early decommissioning represents economic losses for forest companies. The investigations conducted under laboratory conditions involved hardness measuring HV10 and HRC, wear resistance testing of materials by friction against loosely fixed abrasive parts, with assessment profile and depth of the mark as well as assessment of quality mixing of the layers, microstructure assessment by SEM with EDX analyses. By evaluating the laboratory tests, the conclusions were drawn to determine the suitability or the non-suitability of the selected hardfacing material in service. Whether the material increases the service life of the undesirable crusher tool, will by verified by performing field trials.
\end{abstract}

Keywords: hard facing, forestry tools, abrasive wear, microscopy analyses, hardness

\section{INTRODUCTION}

The tools used in forestry are not given as much attention as e.g. the tools used in agriculture, in mining and quarrying, in road building and modifying, and so on. They operate in a heterogeneous environment where they are subject to abrasive wear. This results in their relatively early decommissioning [13]. At the same time, their price is a significant item for forestry companies. The resistance to abrasive wear of exposed machine parts, tools, etc. is generally achieved by technological intervention on the surface in order to qualitatively change the properties of the base material. Such interventions need to be first verified by relevant tests and measurements under laboratory conditions. Only those innovations that achieve the best results can be applied to the tools and tested under real working conditions [11].

\section{MATERIAL AND METHODS}

The tools for crushing of undesirable advance growth are fixed on the rotor - the adapter of the forest wheeled tractor. On average, they comprise 48 pieces. They are made by means of thermoforming technology, so they are forgings. According to the research reported in $[13,6]$, the tools made of $15 \mathrm{MnCr} 5$ steel do not meet the conditions under which they work, because of their mechanical properties and a ferritic-pearlitic structure in not heat-treated state after losing the WC tips mounted on the tool body. They are object of strong abrasive wear in the heterogeneous environment, which is associated with shock loading. Figure 1 shows a new tool and a damaged tool that is out of service.

According to the results in reported [13], the significant plastic deformation formed below the 
surface from the cyclically repetitive abrasive load of the tool surface (high speed of the adapter rotor) causes the tool surface to harden. This is manifested by the separation of material parts (Fig. 2a). Surface craters are formed (Fig. 2b). Fig. 2c indicates the depth of plastic deformation at a depth of about $0.2 \mathrm{~mm}$.

The hard facing technology is a metallurgical process in which a filler material is added to a base material. Hard facing process occurs by the efficiency of the external heat source. During this process, weld deposit - layer of homogeneous metal is created, formed by metal alloy of the filler and base material on the base material surface. They are mixed in the transition area and the chemical composition and microstructure are also changed. Therefore, in most cases, the multilayer weld deposits are used, where the necessary chemical composition and properties of the weld deposit are achieved in the second or third layer. Optionally, the interlayer is used before the hard facing process.

Hard facing creates a layer that can protect the base material from its significant damage and obtain the properties that resist environmental conditions. Greater resistance to individual types of stress and corrosion is achieved [1]. The metals for hard facing can be divided into groups according to their characteristics and wear resistance.

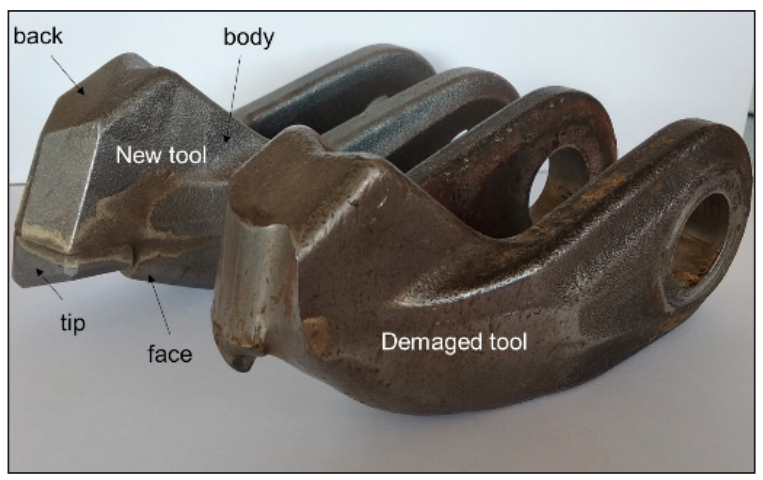

Fig. 1. New and damaged tool for crushing of undesirable advance growth
The iron-based alloys are divided into martensitic, austenitic and high carbide alloys. It is characterized by excellent abrasion resistance, good heat resistance, acceptable corrosion resistance and poor impact resistance. It is stated in $[5,14]$ that the carbide size also has a significant impact on the abrasion resistance. Long carbides $\mathrm{M}_{7} \mathrm{C}_{3}$ are characterized by the best durability because they have better cohesion with the matrix and do not break as easily as shorter carbides.

According to $[3,10,12]$, the weld deposit with WC has a typical composition - around $60 \%$ particles of WC and the remainder is low-carbon steel. It is characterized by excellent resistance to abrasive and erosive wear, but the weld deposit tends to crack during the hard facing.

The welding filler rod RD 571 was selected for the experiment. It is designed for manual flame hard facing on the surfaces extremely stressed by abrasion and shocks (crushing jaws of earthmoving equipment, functional parts of kneading devices, etc.). It is a special hard facing material made of $\mathrm{W}_{2} \mathrm{C}$ carbides in a steel matrix, produced in VÚZ Bratislava. It has good operational properties, but depositing of the weld beads is challenging and requires some welder's skill. The attainable hardness in the second layer is 65 HRC, minimally [20]. The chemical composition of the welding filler rod RD 571 and base material is shown in the Table 1. The hard facing conditions are listed in Table 2. The hard weld was applied in two layers.

The laboratory evaluation of the hard facing material was performed. The following tests and analyses were carried out on the samples taken:

- measurement of hardness with HV10 and HRC methods;

- evaluation of resistance to abrasive wear;

- evaluation of profile and trace depth on hard facing material after abrasion resistance test;

- microscopic analysis - luminous and SEM with EDX analysis.
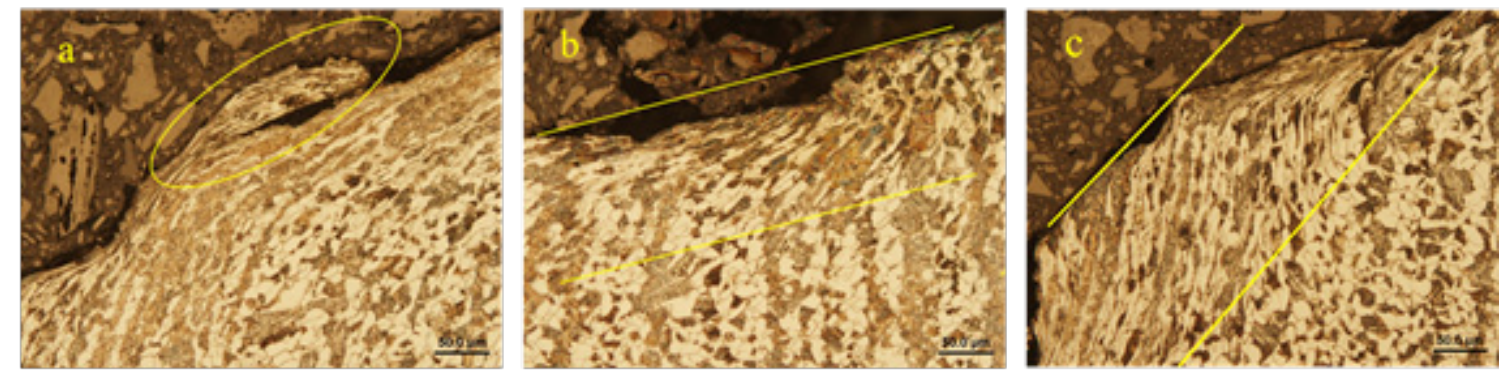

Fig. 2. Plastic deformation on the back surface of the tool [13] 
Table 1. Chemical compositon of the welding filler rod and base material [wt $\%$ ]

\begin{tabular}{|c|c|c|c|c|c|c|c|}
\hline \multicolumn{7}{|c|}{ Welding filler rod RD 571 for manual hard facing by flame } \\
\hline $\mathrm{C}$ & $\mathrm{Si}$ & $\mathrm{Mn}$ & $\mathrm{Cr}$ & $\mathrm{Ni}$ & $\mathrm{B}$ & $\mathrm{W}_{2} \mathrm{C}$ & $\mathrm{Fe}$ \\
\hline 0.10 & 0.80 & 0.50 & 5.0 & 15.0 & 0.3 & 60 & rest \\
\hline \multicolumn{7}{|c|}{ Base material $16 \mathrm{MnCr} 5$} \\
\hline 0.212 & 0.24 & 1.30 & 1.22 & - & - & - & rest \\
\hline
\end{tabular}

Figure 3a shows a part of tool from which the samples were taken for individual analysis.

Vickers hardness was measured by a Vickers hardness tester 432SVD according to STN ISO 6507-1:2006 [16]. Load force value $\mathrm{F}=98.07 \mathrm{~N}$ with load duration $\mathrm{t}=15 \mathrm{~s}$. The tables from $\mathrm{STN}$ EN ISO 6507-4:2006 [17] were used to determine the HV10 hardness values (Fig.3b. Rockwell hardness test was performed using the methodology according to STN EN ISO 6508-1:2006 [18]. The measurement was carried out on a $\mathrm{UH} 250$ universal hardness tester with load force value $\mathrm{F}=1471 \mathrm{~N}$.

The preparation of the samples and wear resistance testing of material was performed according to GOST 23.208-79 - Wear resistance testing of materials by friction against loosely fixed abrasive particles [14]. This method compares the loss of the test material and the loss of the standard material under the same test conditions. The standard values were obtained when the base material $15 \mathrm{MnCr} 5$ was tested. OTTAWA silica sand with a grain size up to $0.3 \mathrm{~mm}$, moisture up to $1 \%$ and the $\mathrm{SiO}_{2}$ content above $96 \%$ was used for testing. Hardness corresponds to the seventh degree of the Mohs scale of mineral hardness [2,19] and the hardness value to approximately and 54 HRC, respectively. Three samples with dimensions $30 \times 20 \times 10 \mathrm{~mm}$ were prepared and were cutter with AWJM technological method. Next, they were milled and ground on a planar magnetic grinder to obtain precise dimensions and surface roughness. A Neox Plu confocal microscope was used to observe the profile and trace depth after the abrasive wear test.

Table 2. The hard facing conditions of the welding filler rod RD 571 for manual hard facing by flame

\begin{tabular}{|c|c|}
\hline Parameters & Values \\
\hline $\begin{array}{c}\text { Welding filler rod } \\
\text { dimensions }\end{array}$ & $\varnothing 3.2 \times 450 \mathrm{~mm}$ \\
\hline Preheating & Without heating \\
\hline Hard facing method & $\begin{array}{c}\text { Oxy-acetylene flame }- \text { slightly } \\
\text { carburetting }\end{array}$ \\
\hline Welding filler rod yield & $98 \%$ \\
\hline
\end{tabular}

An etching solution $120 \mathrm{ml}$ of $\mathrm{CH}_{3} \mathrm{COOH}$, $20 \mathrm{ml}$ of $\mathrm{HCl}, 3 \mathrm{~g}$ of picric acid, $144 \mathrm{ml}$ of $\mathrm{CH}_{3} \mathrm{OH}$ (Cor) were used to induce the weld deposits structure. A $2 \%$ solution of $\mathrm{HNO}_{3}$ and ethanol (Nital) were used for etching of the base material. The Olympus CX71 inverted metallurgical microscope with Olympus DP12 camera was used for the microstructure analysis - the quality of the hard facing materials and the mixing state of the base material - the tool body and the weld deposit layers. A Jeol JSM 700F scanning electron microscope with the EDX Oxford Instruments was used for local chemical elements analysis. For the EDX spectra without standard analysis (standardless ZAF analysis), the results of which were semi quantitative with an accuracy of $2 \%$ of the calculated element concentration. Composite mode - COMPO - was used in the reflected electron mode. In this mode, it is possible to distinguish between the areas with different elements composition. Low atomic regions are dark and regions with higher atomic numbers are bright.

\section{EXPERIMENT}

In the tests, the standard test conditions for each mechanical property evaluation method as well as the microscopic analysis were observed at ambient temperature.

\section{Measurement of hardness}

Vickers hardness was measured in two parallel directions from the weld deposit into the base material (Fig.4.). The hardness course is shown in Fig.4. The thickness of the weld deposit is about $2.5 \mathrm{~mm}$. The authors noticed a significantly higher hardness than in the base material, $825 \mathrm{HV} 10$, on average. A second indent of line number 1 indicates that a very hard particle was captured with the measured value of $1200 \mathrm{HV} 10$. It is probably $\mathrm{W}_{2} \mathrm{C}$ carbide, which contains the weld deposit. The waveform curves in the graph are not completely jumped. It is possible to observe a transition area 
a)

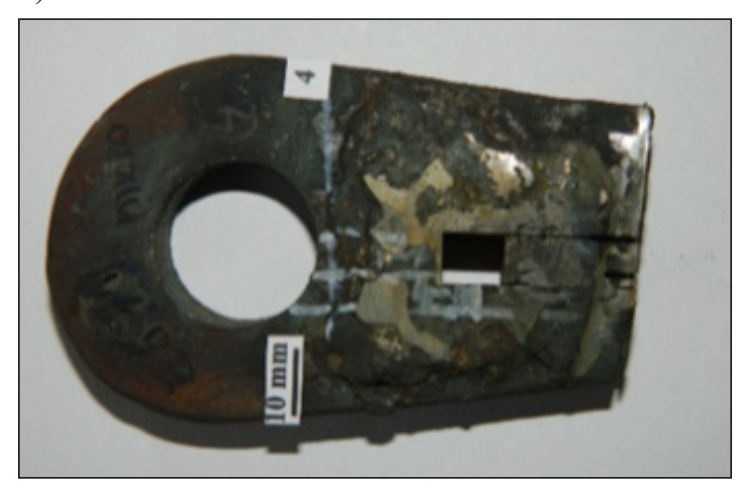

b)

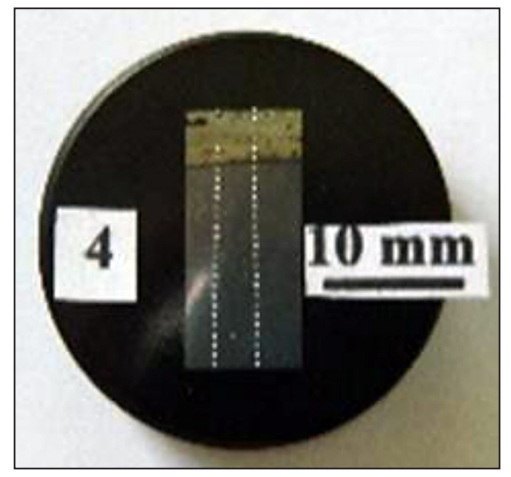

Fig. 3. Part of tool for individual tests and analysis (a); measurement of hardness by HV10 on the prepared sample (b)

of about 1.0 to $2.0 \mathrm{~mm}$ in thickness between the first layer of the weld deposit and base material. This would indicate the presence of HAZ.

The hardness of weld deposit layer was measured by means of the Rockwell method. The average of the three measurements is given in Table 3. For comparison, the hardness value HRC of the weld deposit shown in the technical sheet of an electrode as well as the hardness of the basic material $16 \mathrm{MnCr}$ are also given here.

\section{Measurement of wear resistance}

The measurement of weld deposit resistance to abrasive wear was performed according to GOST 23.208-79. Three samples were tested. The coefficient values of weight loss $\mathrm{W}_{\mathrm{h}}$, relative abrasion resistance $\psi_{\mathrm{h}}$ and coefficient of hardness $\mathrm{K}_{\mathrm{T}}$ are given in Table 4. For comparison, the table also contains the etalon values obtained by the experiment published in [13].

The hard facing material has a significantly higher abrasion resistance value and also higher resistance to the abrasive used in the test. The sample surface after the abrasive wear test is shown in Figure 5. The weld deposit contains a number of $\mathrm{W}_{2} \mathrm{C}$ carbides. The cavities are visible below the surface causing damage to the surface due to abrasive particles in the test.

The Figure 6 shows the profile and depth of the roll of the device on the test sample captured by confocal microscope. High wear resistance is also reflected on the track profile. Uneven material removal was recorded. The maximum trace depth value was $P_{t}=141 \mu \mathrm{m}=0.141 \mathrm{~mm}$. This is less than the detected thickness of material loss in plastic deformation found on the back of a worn material.

\section{Evaluation of microstructure by light microscopy}

The Figure7a shows the interface of the tool base material - weld deposit RD571 with a visible heat affected area. The basic material of the tool is made of perlite and ferrite. Unevenly distributed carbides and pores are visible in the weld deposit (Fig. 7b).

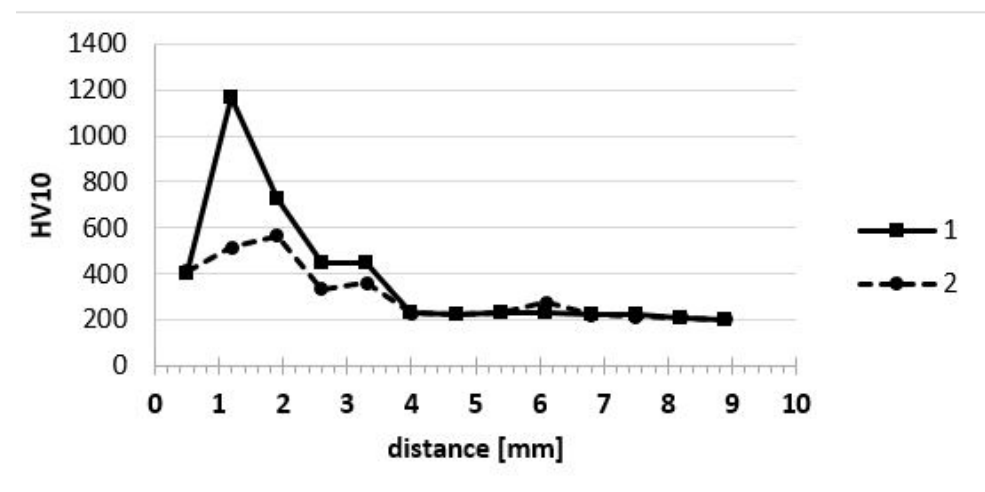

Fig. 4. Hardness course of HV10 of the test sample 
Table 3. Rockwell hardness values HRC

\begin{tabular}{|c|c|c|}
\hline $\begin{array}{c}\text { Value } \\
\text { HRC - measure }\end{array}$ & $\begin{array}{c}\text { Value } \\
\text { HRC - producer }\end{array}$ & $\begin{array}{c}\text { Value HRC - basic } \\
\text { material }\end{array}$ \\
\hline 60 & $\min .65$ & $18 \pm 1$ \\
\hline
\end{tabular}

Table 4. Coefficient values

\begin{tabular}{|c|c|c|c|}
\hline Coefficient & $\mathrm{W}_{\mathrm{h}}[\mathrm{g}]$ & $\Psi_{\mathrm{h}}$ & $\mathrm{K}_{\mathrm{T}}$ \\
\hline $\mathrm{RD} 571$ & 0.018 & 5.175 & 1.33 \\
\hline $15 \mathrm{MnCr} 5$ - etalon & 0.099 & 1 & 0.4 \\
\hline
\end{tabular}

The Figure 8a shows the overall disposition of the RD 571 weld deposit electrode etched in COR. A small, etched part of the base material is visible here. Unevenly distributed carbides are visible in the weld deposit. Pores are present in the top of the second layer of the weld deposit. Figure $8 \mathrm{~b}$ shows the interface of the weld deposit layers. Figure $8 \mathrm{c}$ captures the interface of the base material and the first weld deposit. As can be seen from Figure 7 and 8, the base material was joined by mixing it with the first layer of the weld deposit as well as the layers of the weld deposits between them. However, pores are observed at the interfaces which are a potential initiator of peeling off of the layers during the abrasive load of the weld deposit in operation. Moreover, the cracks in the weld deposit through carbide grains; they can cause carbide crumbling and peeling them from the matrix. It can lead to rapid wear of the weld deposit.

The Figure 9a. shows the local integrity defects on the surface of the weld deposit RD571. Pores are also observed. Cracks occur in carbides and also in the base material of the weld deposit. Figure 10b shows the detail of the cracks in the weld deposit matrix as well as the carbides present.

\section{Evaluation of microstructure by electron microscopy}

The Figure 10 shows the SEM images for the carbides in the Fe matrix of the weld deposit, in the chemical contrast mode (COMPO). The bright areas represent an elements with a higher atomic number (WC carbides). Figure 11a shows the interface of the base material and the weld deposit RD571 and Fig.10b shows the detail of this interface.
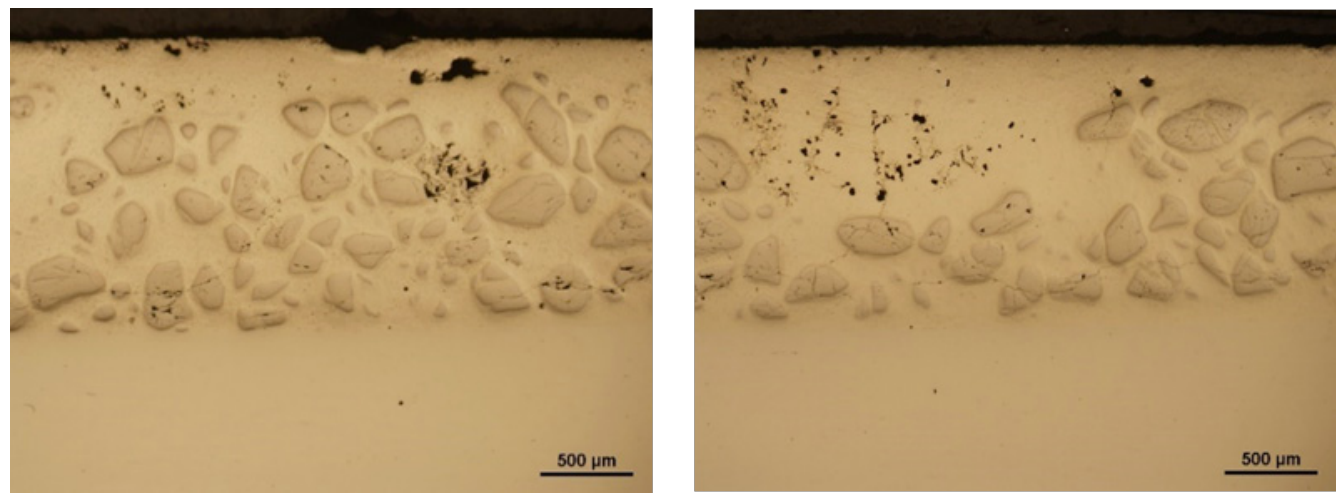

Fig. 5. Part of the track surface profile after abrasive wear test
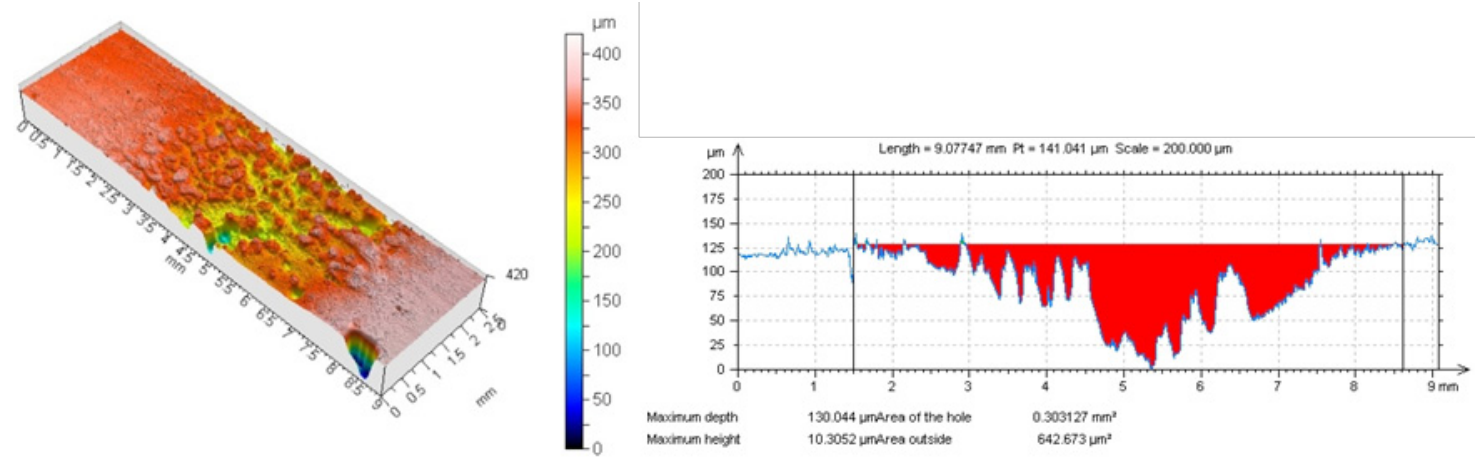

Fig. 6. Profile and trace depth after abrasion resistance test 
a)

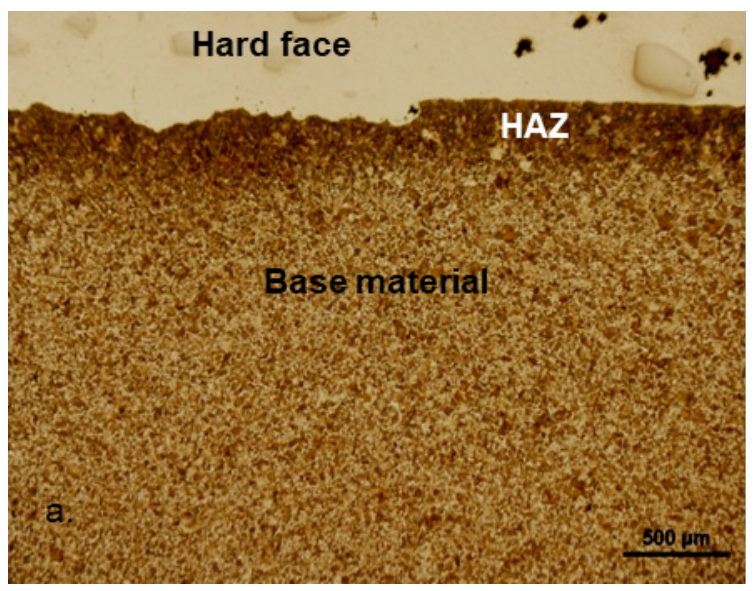

b)

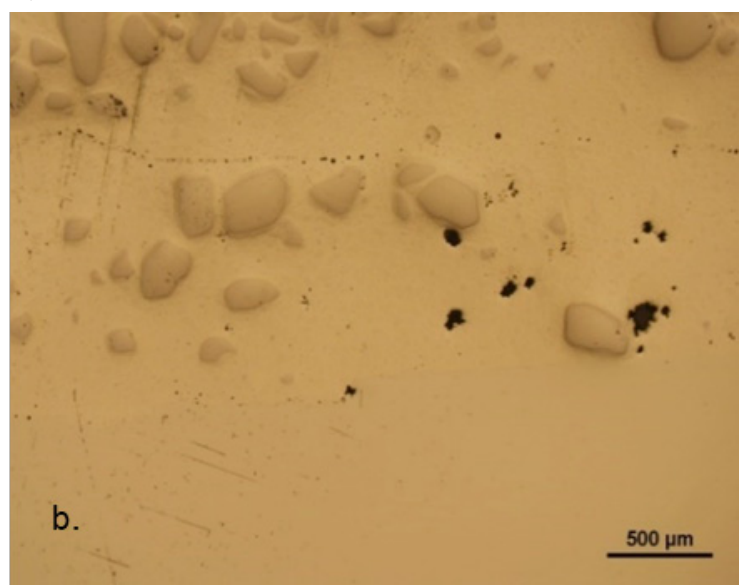

Fig. 7. Weld deposit RD 571; connection the base material and the first layer of the hard weld deposit (a); weld deposit on the base material (b)
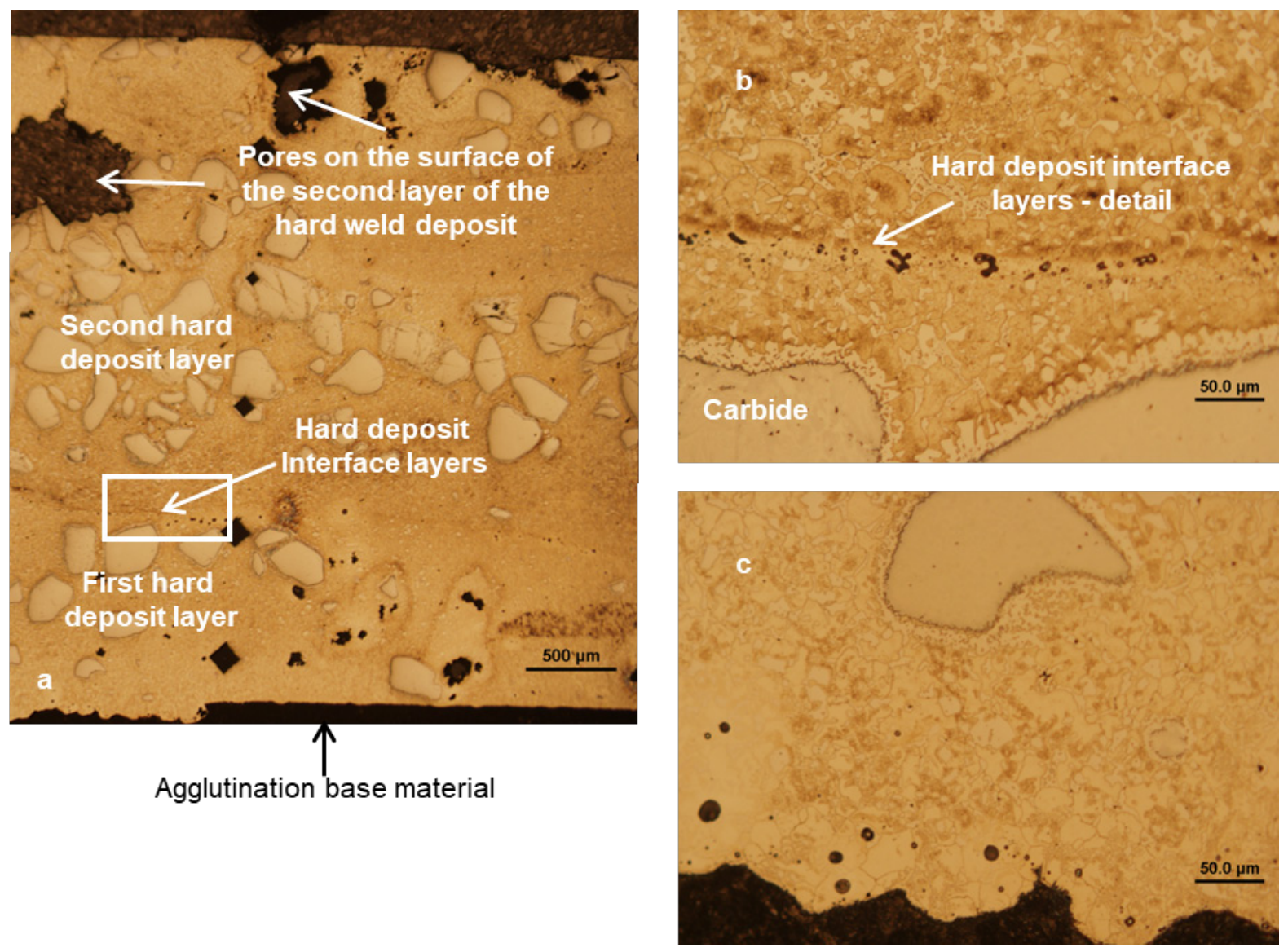

Fig. 8. Overall disposition of the hard weld deposit electrode RD 571 (a); interface view (b)

The Figue 11. shows the EDX microanalysis of the weld deposit RD 571 and around the boundary of the weld deposit and base material. Carbides (Point "1" and Point "4") are visible in the weld deposit as the sharp-edged particles. Their shape can cause peeling from the matrix at high load of the weld deposit. In addition to large, sharp-edged carbides, there are also small carbides. Therefore, an area analysis was carried out in this place (Area " 3 ").

A lighter zone with a thickness of up to 10 $\mu \mathrm{m}$ is observed in Figure 11 at the interface of the weld deposit and base material. The point analysis was also carried out at this point. It is continuously visible in Figure 11a. A high iron value was found in this zone by chemical 

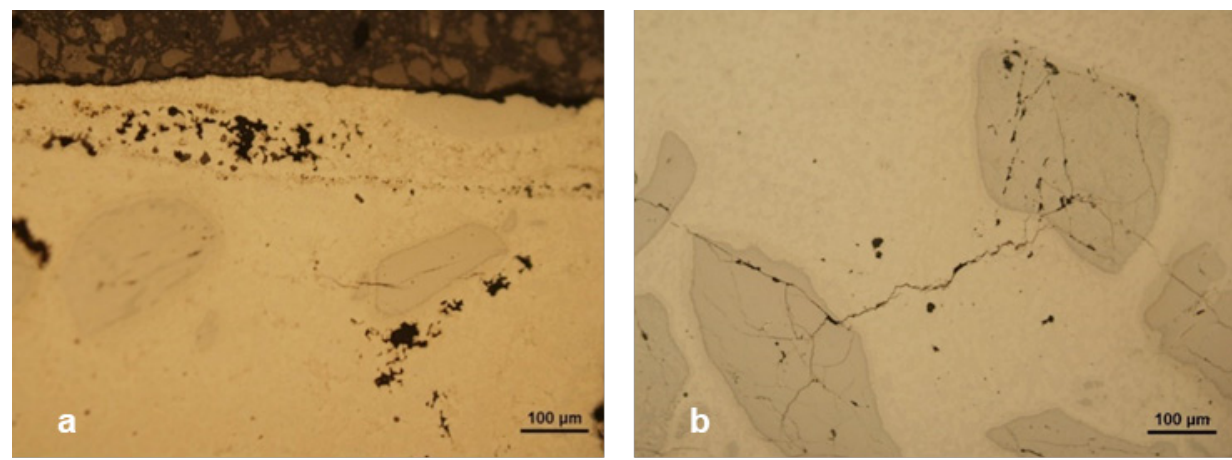

Fig. 9. Hard weld deposit with pores and cracks (a) detail - cracks in the matrix and carbides (b)
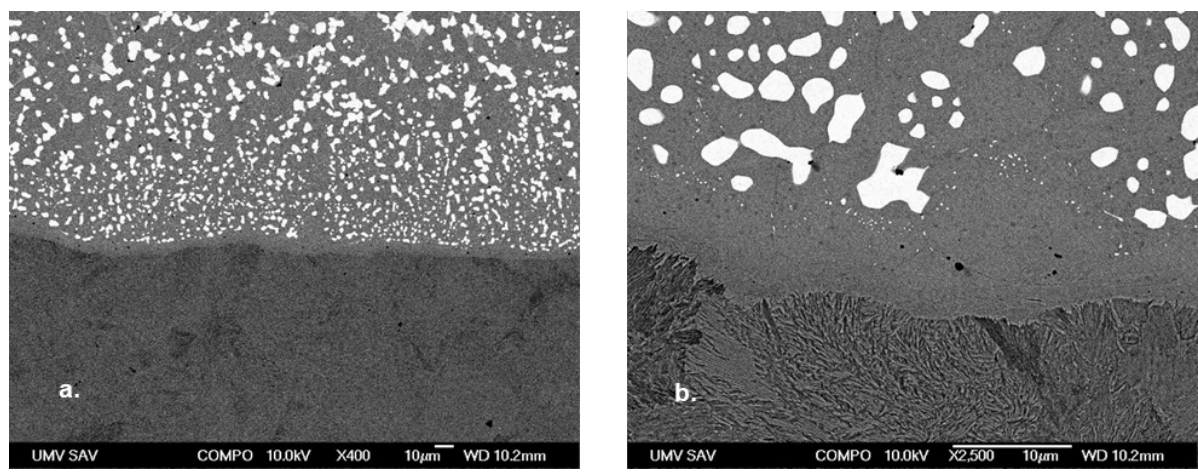

Fig. 10. Tool material interface; weld deposit (a); interface detail (b)

analysis (Table 5 - Point " 2 " of EDX analysis). There is probably a diffusion connection but without the presence of the carbides. This probably confirms that the materials were not mixed at the interface. The importance of performing the point analysis is given by the fact that the area analysis could also capture locations outside the observed lighter zone in the weld deposit and base material. This could distort the information about the likely zone of mixing

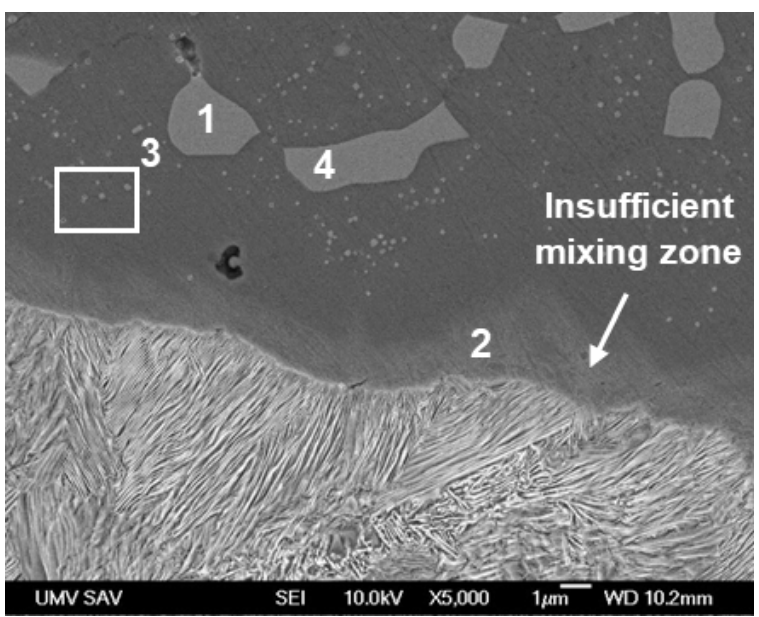

Fig. 11. The EDX microanalysis of the weld deposit RD 571 on the base material that can cause the weld deposit inconsistency with the base material.

It can be concluded that the high presence of Fe in the zone of insufficient mixing also indirectly confirms the decrease of the hardness recorded in the graph (Fig. 4). The hardness value of the fifth indent is close to that of the base material.

The price of the new tool for crushing of undesirable advance growth is about $70.00 €$. According to the available information on the prices of the hard facing materials as well as the overheads associated with hard facing, the price of modified tools would increase by $25 \%$. The final price could reach up to $90.00 €$.

\section{RESULTS}

The RD 571 welding filler rod for manual hard facing by flame represents a special high $\mathrm{W}_{2} \mathrm{C}$ material $(60 \%)$ with $\mathrm{Ni}$ content $(15 \%)$. It was assumed that the WC carbides in a steel matrix can cause cracking during hard facing. This was also confirmed by a microscopic analysis of the material samples. However, they have excellent resistance to abrasive and erosive wear $[10,3,20]$. By evaluating the sample using both SEM and 
Table 5. Point and area EDX analysis [\%]

\begin{tabular}{|c|c|c|c|c|c|c|c|c|}
\hline & \multicolumn{2}{|c|}{ Point 1 } & \multicolumn{2}{c|}{ Point 2 } & \multicolumn{2}{c|}{ Point 4 } & \multicolumn{2}{c|}{ Area 3 } \\
\hline \multirow{2}{*}{ Element } & \multirow{2}{*}{ Weight } & Atomic & \multirow{2}{*}{ Weight } & Atomic & Weight & Atomic & \multirow{2}{*}{ Weight } & Atomic \\
\hline C & 3.10 & 23.30 & 2.75 & 11.60 & 4.49 & 31.82 & 4.49 & 31.82 \\
\hline W & 71.12 & 34.97 & - & - & 72.96 & 33.79 & 72.96 & 33.79 \\
\hline Fe & 25.78 & 41.73 & 97.25 & 88.40 & 22.56 & 34.39 & 22.56 & 34.39 \\
\hline Total & \multicolumn{2}{|c|}{100} & \multicolumn{2}{|c|}{100} & \multicolumn{2}{c|}{100} & \multicolumn{1}{c|}{100} \\
\hline
\end{tabular}

light microscopy (Fig. 7-9) it can be said that the base material was joined by mixing it with the first layer of the weld deposit as well as the layers of weld deposits between them. However, pores are observed at the interfaces, which are potential initiators of peeling of the layer during abrasive loading of the weld deposit in service. Moreover, the cracks in the weld deposit through carbide grains; they can cause carbide crumbling and peeling them from the matrix. It can lead to rapid wear of the weld deposit. The EDX analysis documents the visible carbides in the weld deposit as sharp-edged particles. Although the cracks themselves do not significantly affect the particle wear resistance, they may initiate fracture under static or dynamic stress $[7,4,8]$. The shape of the particles can cause peeling from the matrix at high loads of the weld deposit. In addition to large, sharp-edged carbides, small carbides are present in the weld deposit without the presence of micro-cleaners. The point analysis was also performed at the interface of the weld deposit and base material where the lighter zone of up to 10 $\mu \mathrm{m}$ in the thickness was observed (Fig.11). The chemical analysis revealed the high Fe value in this zone. There was probably a diffusion connection but without the presence of the carbides. This confirms that the materials were not mixed at the interface. It can be concluded that the high presence of $\mathrm{Fe}$ in the zone of insufficient mixing also indirectly confirms the decrease of the hardness HV10. The values of $\psi_{h}, K_{T}$ are $W_{h}$ are high. The track depth value was detected at $\mathrm{P}_{\mathrm{t}}=141 \mu \mathrm{m}=$ $0.141 \mathrm{~mm}$. This is less than the detected thickness of material loss in plastic deformation found on the back of a worn material $(0.20 \mathrm{~mm})$. However, together with $60 \mathrm{HRC}$, it may not guarantee a good abrasion resistance. The increased hardness does not automatically mean better wear resistance or longer durability. The metal matrix must resist the scaling effect of the particles and also must prevent the carbides from breaking $[9,13]$.

\section{CONCLUSIONS}

On the basis of the results of laboratory tests and observations, it can be concluded that by applying additional material with a structure more resistant to abrasive particles in a heterogeneous working environment, higher abrasion resistance of the exposed tool surfaces for crushing of undesirable advance growth can be provided. On the basis of the results of laboratory tests and analysis, the limited availability of the hard facing material, worse operating properties and the high cost of tool modification, it can be assumed that this type of the hard facing material would not be suitable for operational testing.

\section{Acknowledgement}

The paper was developed as part of the APVV16-0194 „Research on Impact of Innovation in Production Processes on the Life of Tooling and Components of Forest Mechanisms.“

\section{REFERENCES}

1. Bajga M. Navařovaní kovi̊. Svět svaru. 2017, roč. 9 , č. 2 .

2. Benson E. and Burack W. A. Frac Sand Sources in the United States, U.S. Geological Survey, Denver, Colorado (2015) [Access: 17.05.2019].

3. Dawson R.J., Shewchik S. and Pritchard J.E. Selection and use ofhardfacing alloys, Weld, J. 61 (11), Pp. 15-23, 1982.

4. Greš M. and Viňáš J. Negatívne vplyvy pôsobiace $\mathrm{v}$ procesoch renovácie naváraním Integrovaná bezpečnost'. Proceedings of the international Scientific conference, Bratislava December 18-19, 2014, Strix Žilina, Edition ESE-17, First edition.

5. Chotěborský R., Hrabě, P. et al. 2009. Abrazívní opotřebení návarových materiálů na bázi $\mathrm{Fe}-\mathrm{Cr}-\mathrm{C}$. In: Konstrukce [Access: 2019-05-20]. 
6. Kalincová D., Ťavodová M., Hnilicová M., and Veverková D. Machinery for forest cultivation - increase of resistance to abrasive wear of the tool In MM science journal. November (2016), 1269-1272.

7. Krauze K., Bołoz Ł. and Wydro T. Parametric factors for the tangential-rotary picks quality asessment, Archives of Mining Sciences, 60(1), 2015, 265-281. DOI: 10.1515/amsc-2015-0018.

8. Minárik M. and Hricová J. Log splitter design and construction In. Drvna industrija: znastveni časopis za pitanja drvne technologije. 2015, 11-16.

9. Müller M., Novák P., Chotěborský R. and Hrabě P. Reduction of ploughshare wear by means of carbide overlay. Manufacturing Technology, Vol. 1. 2018.

10. Suchánek J. Návarové slitiny do podmínek abraze [Access: 20.04.2019].

11. Sujová E., Čierna H. and Hnilica R. Methodology proposal for identifying life-cycle costs (LCC) of mulchers of undesirable growth. MM Science Journal, 2016, 1166-1170.

12. Šebek M., Falat L., Kováč F., Petryshynets I., Hornak P. and Girman V. The effects of laser surface hardening on microstructural characteristics and wear resistance of AISI H11 hot work tool steel. Arch. Metall. Mater. 62(3), (2017), 1721-1726. DOI: $10.1515 / \mathrm{amm}-2017-0262$.
13. Ťavodová M., Džupon M., Kalincová D. and Hnilicová M. Deformation of exposed parts tool for crushing of undesirable advance growths In Acta technologica agriculturae, 21(4), (2018), 169-176.

14. ESAB Slovakia - Katalóg produktov [Access: 20.04.2019].

15. ГОСТ 23.208-79 Обеспечение износостойкости изделий. Метод испытания материалов на износостойкость при трении о нежестко закрепленные абразивные частицыhttp [Access: 02.05.2019].

16. STN EN ISO 6507-1:2006 Kovové materiály: Vickersova skúška tvrdosti. Čast' 1., Skúšobná metóda. SÚTN Bratislava.

17. STN EN ISO 6507-4:2006 Kovové materiály: Vickersova skúška tvrdosti. Čast' 4., Tabul'ky hodnôt tvrdostí. SÚTN Bratislava.

18. STN EN ISO 6508-1:2006 Kovové materiály: Rockwellova skúška tvrdosti. Čast' 1., Skúšobná metóda (stupnice A, B, C, D, E, F, G, H, K, N, T) SÚTN. Bratislava.

19. Stupnica tvrdosti nerastov [Access: 17.05.2019].

20. Výskumný ústav zváračský - Priemyselný inštitút SR Bratislava, Prídavné materiály [Access: 20.03.2019]. 